\title{
Endovascular Management of Vascular Complications Related to Percutaneous Renal Procedures
}

Perkütan Renal Girişimlere Bağlı Vasküler Komplikasyonların Endovasküler Tedavisi

\section{Çağatay Bölgen, Mustafa Mazican, Murat Gedikoğlu, Çağatay Andiç}

Başkent University Faculty of Medicine, Adana Research Hospital, Department of Radiology, Adana, Turkey

\section{Introduction}

Our aim was to present the technical success and safety of selective endovascular treatment of renovascular complications related to percutaneous renal procedures.

Pseudoaneurysm, renal haemorrhage and arteriovenous fistula are common complications of percutaneous renal interventions, such as percutaneous nephrolithotomy, percutaneous nephrostomy tube placement and renal biopsy (1). While conservative follow-up is an acceptable and non-invasive choice, if the patient becomes dynamically unstable, management of these complications can be achieved either by open surgical procedures or minimally invasive endovascular embolization (2). Complications of endovascular embolization, such as renal artery dissection, post-embolization syndrome and loss of renal function are rare. However, superselective embolization performed as distal as possible minimizes the parenchymal loss of functional renal tissue (1). We present 3 patients (two native kidney, one transplanted), suffering from renovascular complications after percutaneous renal procedures, treated with transarterial selective renal embolization.

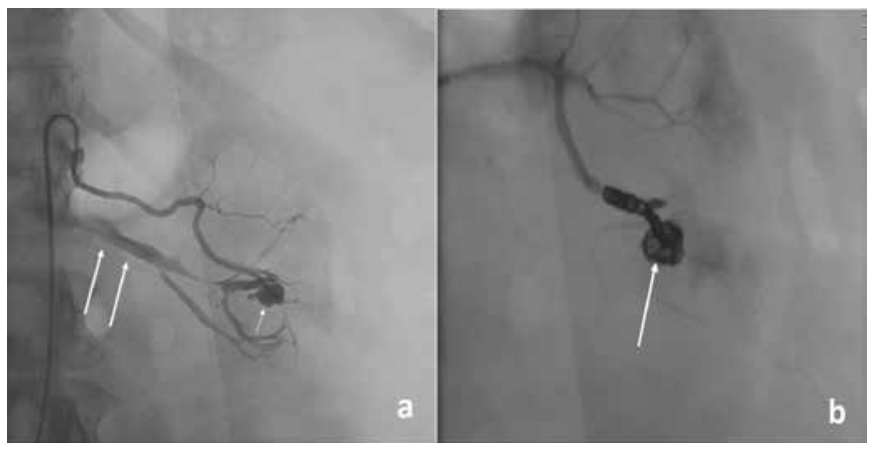

Figure 1. a) A 51-year-old woman's left renal selective angiogram after percutaneous nephrolytotomy shows a pseudoaneurysm (short arrow) and an early venous return (long arrows) suggesting an arteriovenous fistula, b) Pseudoaneurysm is filled with coils (arrow); the venous return is no longer seen
In all 3 patients, distal access to the lesions was gained with a microcatheter and embolization was performed with coils (Figure $1,2,3)$. No complications occurred. The post-operative course was uneventful in all patients.

Endovascular treatment, especially selective renal artery embolization, is a safe and effective, minimally invasive alternative

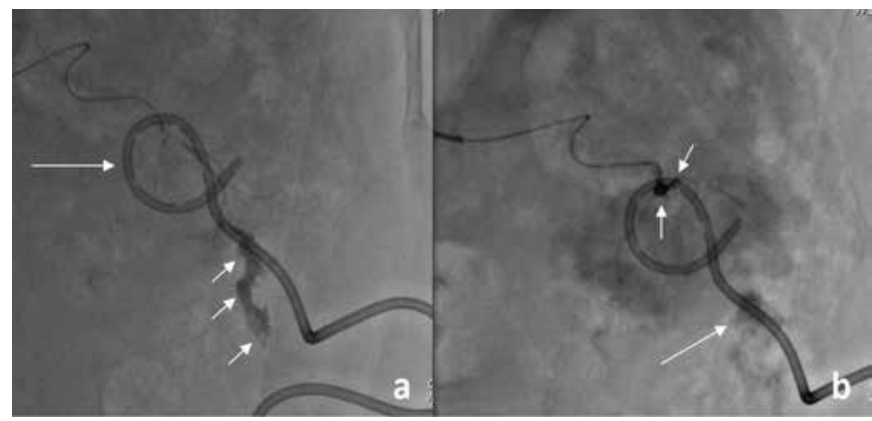

Figure 2. a) A 69-year-old man's left renal selective angiogram after percutaneous nephrostomy tube (long arrow) placement shows a haemorrhagic tract (short arrows), b) After coiling (short arrows), the haemorrhagic tract does not persist (long arrow) while some contrast agent related to initial angiogram appears

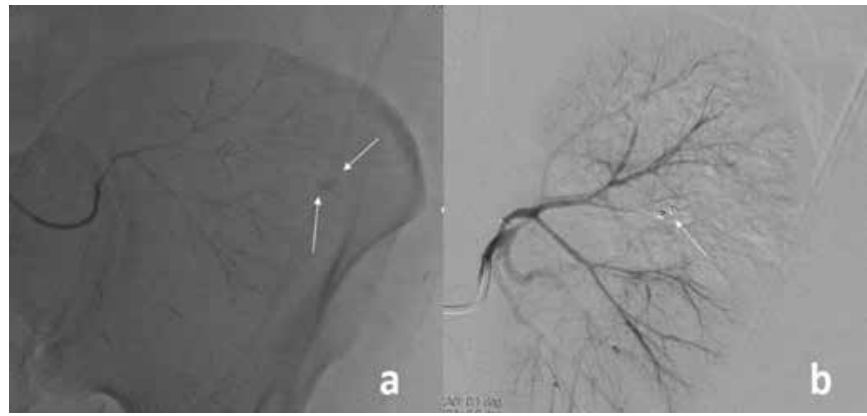

Figure 3. a) A 36-year-old man's transplanted kidney selective angiogram after parenchymal biopsy shows an active bleeding (arrows), b) The bleeding was controlled with coil embolization (arrow)

\section{Correspondence}

Çağatay Bölgen MD, Başkent University Faculty of Medicine, Adana Research Hospital, Department of Radiology, Adana, Turkey

Phone: +90 3223272727 E-mail: cagatbey@hotmail.com Received: 03.02.2016 Accepted: 08.02.2016 
procedure for vascular complications related to percutaneous renal procedures.

Anahtar Kelimeler: Embolizasyon, renal, vasküler, renovasküler, komplikasyon, perkütan

Keywords: Embolization, renal, vascular, renovascular, complication, percutaneous

\section{Ethics}

Peer-review: Internal peer-reviewed.

\section{Authorship Contributions}

Concept: Çağatay Andiç, Design: Çağatay Bölgen, Data Collection or Processing: Murat Gedikoğlu, Analysis or Interpretation: Mustafa
Mazican, Literature Research: Çağatay Bölgen, Writing: Çağatay Bölgen. Conflict of Interest: No conflict of interest was declared by the authors. Financial Disclosure: The authors declared that this study has received no financial support.

\section{References}

1. Güneyli S, Gök M, Bozkaya H, Çınar C, Tizro A, Korkmaz M, Akın Y, Parıldar $M$, Oran I. Endovascular management of iatrogenic renal arterial lesions and clinical outcomes. Diagn Interv Radiol 2015;21:229-234.

2. Mavili $E$, Donmez $H$, Ozcan N, Sipahioglu M, Demirtas A. Transarterial embolization for renal arterial bleeding. Diagn Interv Radiol 2009;15:143147. 